\title{
Beyond Good Governances: Lesson from Forest and Cultural Governance in Pelalawan, Pangkalan Kerinci, Riau
}

\author{
Novi Paramita Dewi ${ }^{1}$ \\ Tauchid Komara Yuda ${ }^{2}$
}

\begin{abstract}
The shift in government concept into governance takes the consequence of changes in public governance including in the forestry sector. Good forest governance becomes a great hope for managing the forest condition so that sustainable forest management can be realized. However, in its implementation, it contains a big challenge for the forest in Indonesia which is mostly identical with indigenous people. Meanwhile, the development becomes a necessity that cannot be inhibited in which business corporation as the actor who plays in the forest governance is considered as a major threat to the environment and indigenous people. To achieve good forest governance, it is necessary to have a synergy with cultural governance that is hoped to be able to accommodate the indigenous people interests. This paper is a case study related to the practice as an effort to achieve good forest governance in the indigenous people of Pelalawan that are followed by the cultural governance effort so that the indigenous people culture of Pelalawan that is closely related to the forest can still be maintained.
\end{abstract}

\section{Keywords:}

forest governance; cultural governance; indigenous people.

\section{Introduction}

During a discourse of the world of business' expansion will always be intersected with the public interest towards environment, livelihood, and even accessibility towards any other public related things (Lertzman and Vredenburg 2005). This happens because the proportion of business paradigm that is built is fully focused its attention only towards profitability (Yuda 2016), without seeing local wisdom aspect of the expansion area. As we know, that local wisdom has given the local society livelihoods, including social safety network of them if in case there is something contingency happened. This can be understood regarding in indigenous people, attach obligatory norm that is agreed upon widely and reciprocally that promoting cooperation, building solidarity, and helping vulnerable family and individuals, including to influence their point of view towards forest (Jones et.al 2009;Patel, Kaseke and Midgley 2013; Putnam 1993).

This then makes the existence of a company often becomes a dilemma for indigenous people existence. As for the other things that usually happens in the world of business expansion i.e. the struggle for indigenous land rights. Which means, when the company got the legality from the country's law to do exploration and exploitation activities, but the legality is not recognized by the people who

\footnotetext{
${ }^{1}$ Department of Public Policy and Management, Universitas Gadjah Mada.

Email: noviparamita@ugm.ac.id

${ }^{2}$ Department of Social Development and Welfare, Universitas Gadjah Mada.

Email: tauchid.komara.y@mail.ugm.ac.id
} 
still depend on norm and local customary law. In this period, the contest between country and custom becomes the matter that is inevitable on each moment of land clearing. It is still in the end that the indigenous people themselves who become the marginalized party.

This marginalization process is at a later stage, not only about the existence, but also about the dramatic changing of the way of life. For instance, from previously hunting, when there is a company the activity of hunting itself cannot be done. This is because the change of ecology due to expansion activity. By making indigenous people join into the country's system, the indigenous land that previously conquered by indigenous people is diverted its management rights to the government. Thus, there are many cases, so that this indigenous land should alter its function, including becoming industrial concession land. The consequence is that the society can no longer harness the existing land "collectively", but they can harness "the less" for collective importance. Furthermore, this issue triggers forest resources management issues where the forest is the location of indigenous land that are exist. Forest resources management should follow the industrial development and leave the old pattern that has actually been conserved by indigenous peoples.

To reconcile between the interests of economy sector, socio-cultural and environmental aspect in forest governance and culture in it, idea is needed towards public partnership in order to manage the all three. The idea of a public partnership in this case refers to the concept of good governance which puts actors of the interests into public policy (Lamichhane and Parajuli 2014; Mutekwa and Gambiza 2016; Pokharel and Tiwari 2013) by mainstreaming indigenous administration in its implementation. This can be done with the hope that bigger access towards forest resources including in decision-making and the role of control in an attempt to achieve
Sustainable Forest Management (SFM). From various studies (Cagalanan 2015; Cronkleton, Bray and Medina 2011; Johanasson 2013) that have been done to confirm that the forest management system based on local wisdom can increase the effectiveness in forest management purposes that are expected, that is to preserve and improve the quality of the environment and welfare, values and local wisdom that are available in the forest, followed by the quality of life for those whose livelihoods depend on this sector (Mutekwa and Gambiza 2016).

The concept of forest governance which is closer to the principles of SFM can be seen at one example of indigenous forest in Pelalawan, Pangkalan Kerinci Town, Riau, which involves indigenous peoples and plantation companies and palm oil industry like Riau Andalan Pulp and Paper (RAPP) as one of the several factories of land concessions. The thing that makes it interesting is that even though Companies legally control the area of indigenous forest, but for the affairs of forest governance that is done, it turns out to involve a dialogue between the government, enterprises, and the indigenous people themselves. This dialogue was conducted based on the initiative of three interest actors, i.e. indigenous leaders who wanted to get their cultural rights, companies with an interest in creating a conflict-free business climate, and the government as a mediator with ethical responsibility as a public service. So that its output, the institutional arrangements that is produced is able to form governance not only promote the local community participation and more democratic, but also encourage the innovative use of the forests. Even so, there is no doubt that there is still a trade-off (Stiglitz, 2000) among the three interests, which then implies a shift value, collective identities and the development of indigenous people's culture very attach to forests.

What has been practiced in the case of forest governance and culture in Palalawan eventually become a form of a reference for different forest governance from governance 
policies standards of forest resources at the moment, which tends to look local people is forest destructors (Massiri et. al 2016). In further discussion, this article is divided into three main discussions. In the first part, this article will explain the concept of good forest governance and cultural governance. The second part is Industrialization and Contemporary "Forest Culture" of Palalawan Tribe. In the third part, it will present the realization of SFM in Palalawan Forest governance.

\section{Methods}

This study will orbit on the issue of forest culture governance, with the object of the study concerning to contemporary Palalawan Tribe forest culture governance in the period of Palalawan industrialization. Therefore, the case study option of the researcher is used as a base the operational logic of research by considering the reason that, the formulation of the issues raised basing on special case, which is limited to time periods and specific themes, with research questions starting with the logic of why and how (Yin, 2003 in Baxter and Jack, 2008: 544). The question of why and how show that the target finding in this study is the history of developed process over certain period of time (see: Cresswell, 2013: 106). So as to provide a narrative about the urgency of the issues to be raised with the intention that the researcher / writer can determine the perspective that is used when interpreting and analyzing the obtained data.

The used data comes from an interview from the traditional leaders, who focuses on the related development of indigenous administration itself during the period of industrialization. Next, the local Government, who the researcher asked information about bargaining position space of indigenous peoples that is given by the government in producing environmental governance regulations in order to categorize the dominant positions of each actor interests. Finally, the companies are interested in the area. In addition to interviewing each actor, the researchers also need to do the following FGD in order to complete the secondary data so that the result that is received can be processed until close to precision for writing report purpose.

\section{Good Forest Governance and Cultural Governance}

Good governance is a fundamental concept to achieve a positive outcome and sustainable development in the sector, including efficiency in resource management, increased contribution to economic growth, service to the environment, and equitable distribution of benefits (World Bank, 2008). In relation to the politics of natural resources, good governance becomes a vital element for sustainable development (Collier 2007). Political governance commitment based on sustainable development will produce more outcomes in better environment governance. Governance refers to how an authority applied to the management of state affairs, including legal and regulatory systems that are planned and its implementation as it has been operated (Castren and Pillai, 2011).

Dissemination of good governance concept in the forestry sector can be based on a model of good forest governance. Good forest governance is characterized by the predictable policy-making, open, and informed based on a transparent process, a bureaucracy imbued with professional ethos, executive as the arm of the government that ensures accountability in each section, and a strong civil society participating in decision making of a management of a sector and in other public affairs, all of which goes under the rule of law. Thus, the main elements of good forest governance including the adherence to the rule of law, transparency and low levels of corruption, involving all stakeholders in decision-making, accountability of all officials, low load and a stable political rules (World Bank, 2008).

Good forest governance must be supported by institutional level managerial capabilities in both formal and informal in order to 
obtain and use the authority in managing the resources of a forestry sector, to maintain and improve the welfare and the quality of life for those who depend on the sector (World Bank 2008). In further discussion, forest governance also set the formulation, administration and implementation of policies, legislation, regulations, guidelines, norms related to ownership, access, rights, obligations, to achieve Sustainable Forest Management (SFM), both at local and national levels (Ramadhani, 2010). SFM is a forest management based on the management approach that balances environmental objectives, socio-culture and economic in line with forest principles (United Nations, 1992b in FAO, 2003). The main objectives of forest governance are resource efficiency, increased contribution to economic growth and services to the environment, and equitable distribution of benefits.

The achievement of SFM is determined by the level and quality of the development policy support, legal conditions, and institutional of forest governance (Mayers et.al, 2005). Much evidence suggests even in countries that is rich in forests with good market access, does not indicate that the forest sector drives the national development, economic growth and the reduction of poverty level if the forest management was plagued by corruption and poor governance (Castren and Pillai, 2011). Poor governance will cause various forest issues. Weak governance will be the source of the emergence of problems at the forest level such as deforestation of primary forests, forest cultivation that does not respect the rights and needs of the local citizens, forest management jeopardizes diversity and so on (Mayers et al., 2005).

At the operative level, the use of governance in forest governance contain a huge consequence in an effort to create more collaborative governance by involving three main actors partnership in good governance i.e. government, private and society (Lemos and Agrawal 2006; Sam 2000). This is done to achieve a governance that is sustainable (Grober, 2007; World Commission on Environment and Development 1987) Post Brundland Report definition of sustainable development has evolved from the initial framework and more focus on the socially inclusive purpose and sustainable environmentally economic growth (Sachs, 2015). SFM is considered successful, if it is able to create integrated benefits from maintaining local livelihoods to protect biodiversity and ecosystems created by forests, reducing poverty in rural areas and mitigate some of the effects of climate change (LEDS GP, 2016).

\section{Forest Governance in Indonesia}

In its practice in Indonesia, this forest governance has been referred to the modern forest management based on the principle of sustainable development. This is evident from the commitment of forestry development in Indonesia which aimed at achieving the medium-term vision i.e. the realization of the implementation of forestry to ensure the preservation and improvement of people's welfare. In an effort to achieve this vision, the Forestry Department has also set Five Prioritized Policies that have been established by the Minister of Forestry decree, SK number 456/Menhut/2013 namely (in Hardiani, 2017):

1. Combating illegal logging in State forest and illegal timber trade

2. Revitalization of the forestry sector, especially the forestry industry

3. Rehabilitation and Conservation of Forest Resources

4. Economic empowerment of communities in inside and around forest areas

5. Consolidation of Forest Areas. The five prioritized policies are also supported by a Supporting Policy.

Although the law has led to the vision of a sustainable forest, forest governance that is implemented in Indonesia is still far from the efforts to achieve SFM. This can be identified 
from a violation form towards the sustainable forest management framework that happens in many places. Various cases ranging from ecological imbalances such as peat forest fires which mean that contribute to carbon in the air, economic imbalances such as local employment margin and socio-cultural imbalances such as land tenure conflicts occur almost in various forests in Indonesia. Not only that, even illegal logging, burning, poaching, encroachment of land, trade of fauna and flora that are prone to extinction, and the evasion of taxes and royalties remains a challenge to achieve SFM in Indonesia (Castren and Pillai, 2011; World Bank, 2008).

Another thing that needs to be highlighted, forest governance practice in Indonesia so far seem less able to accommodate the interests of actors in forest governance so that it is still felt harming indigenous peoples. As an alternative in implementing good forest governance in order to achieve SFM, accommodation is necessary towards the interests of the involved actors, especially the indigenous peoples who are generally considered to be the most disadvantaged party in this good forest governance practice. This is because the consequences of good forest governance which resulted in a shift in the local cultural values of indigenous peoples who depend upon the forest so it needs to be bridged by the cultural governance approach on the other side.

Cultural governance is defined as government involvement, both directly and indirectly in promoting and administering the program from a cultural organization that exists in a geography-specific boundary with administrative arrangement and unique financial (e.g., set a certain percentage of the sales or property taxes to support the institution and cultural activities) (Moon, 2001). In a narrow sense, cultural governance can be attributed to political negotiations about the creation of cultural institutions or cultural forms, such as theater, music or opera, and its shape control, people production and the definition of cultural heritage. The concept of cultural governance can also be interpreted as an institutional arrangement which serves as a medium maintenance of expressions, symbols, and the system of cultural orientation of minorities, and especially ethnic group that is oppressed or non-conformist subculture (Schmitt, 2009).

The forms of the organization of good forest governance by synergizing cultural governance is expected to support the creation of SFM. This has been done in forest governance practice which practiced by collaboration between actors and local government, PT. Riau Andalan Pulp and Paper (RAPP), and Pelalawan tribe themselves in managing forest areas that intersect with economic interests of the company and indigenous peoples of Palalawan.

\section{Industrialization and the Contemporary "Forest Culture" of the Pelalawan Tribe}

This section will specifically examine how the process of cultural dynamics of local communities in the Pelalawan Peninsula during and after the industrialization of oil palms. Historically, Pelalawan community has two customary groups: coastal and petalangan. Each customary group covers various tribes or tribal underneath. Both customary groups depend on their daily life on peat ecosystems. In coastal communities, their mobility is limited to Kampar river banks only. Genealogically, they have proximity to the Malaysian family. They are accustomed to managing natural products by nomadic and mobile means. If a land has been consented, then the land is then replanted while moving to open a new land. Indeed the way that is used to open the land is done by burning; however, it does not then become a smoke disaster as we see on television these days. They use spells, mostly on magical tradition, until the process of burning land does not become a disaster. The initial forest 
burning process was made from bonfire points, gradually, and strict guarding of the burning process - not just left behind, like irresponsible forest burners. The ashes of this combustion they use as fertilizer.

Meanwhile, Petalangan custom, they got a part to manage the peat on the land. Their clumps are closer to West Sumatra. They are the ones whose position is in contact with the rapid industrialization of Riau. In Petalangan, it is known as the forbidden jungle. As the name implies, this Forbidden Forest is not allowed to be destroyed, except for the need to add new land of inflammation, or settlement in accordance with local customary agreements. In this Forbidden Forest, there is Rimba Kepungan Sialang. The name of Rimba Kepungan Sialang is derived from the name of a tree named Sialang. This tree is a common tree that usually becomes the place for bees to have a nest. In addition to Rimba Kepungan Sialang, there is also Rimba Simpanan, that becomes a place to live for the various flora and fauna that become the living necessities of Petalangan people that they are kept by custom.

Petalangan people in their daily life have menumbai (taking) the honey of sialang tree. This tradition has been recognized by UNESCO as a world heritage. Menumbai in Indonesian is known as 'take'. Hardware support for this menumbai honey is usually Timbo or buckets, rope, coconut fiber, and a long staircase. The tradition of menumbai (taking) honey is done at night, led by Tuo Squire assisted by the residents. This Tuo Squire then climbs sialang tree, then walk on it while reading the spells and dance without any lights. The spell that is used is considered a communication language to ask permission for the bee to take its honey. For Petalangan custom, the tradition of taking the honey describes the connection or worship or familiarity between humans and bees. Bees are so respected, even it sometimes be cuddled (Interview with TK).

It is necessary to be known that this Sialang Wood has two meaning for Petalangan people: first, as a collegial collective symbol and a symbol of communal ownership simultaneously. That is, according to the honey taking process, the honey that is obtained is then collected and divided into the whole community and local government with a customarily predetermined proportion. Only a small portion that is sold in which the result of the sales is redistributed for the benefit of the Petalangan people. In addition, sialang honey which is believed to be magical is a honey that has supernatural powers, is also used to smear newborn babies as part of the tradition. Second, each timber has the name of each of the Petalangan tribe as a symbol to show the territory. If you come to Petalangan, then call a name of tribe to one of the residents, then automatically he/she will directly direct to the tree that has been named according to the name of the owner tribe. Although rimba larangan (forbidden jungle) has changed its function, but the local community can still clearly remember the exact location of its ulayat land. This is because there is trombo, the natural boundaries that have certain characteristics that has been identified in hereditary although there is a change of land function.

Today this menumbai (taking) honey is still found, it just rimba simpanan that becomes the place for wild bees in absorbing honey slowly began to diminish little by little, as a result of oil palm land concessions. Symptoms of narrowing the area of this jungle savings can be noticed through the honey flavor that slowly began to become bitterer and darker, from the previous feel of legit and clear color. This happens because the only source of flora for this suction bee now comes only from the palm flower. The number of non palm flora that is absorbed by bees is very limited.

Many cases, this concession project leaves only the woods alone without giving the jungle as an inseparable place. Not infrequently, many companies that are deliberately omitted menumbai tradition is by coming during the day, and then 
taking sialang honey without being noticed by the public, because they think that it is the company's absolute land that already owned by the company. The conversion of function of this forbidden forest is admittedly difficult to be monitored because of differences in interpretation concerning formal law and customary laws. The problem is increasingly complex when this formal law becomes the highest legal principle, and then tends to deny the existence of customary law. The result - as the result of data collection when in the field - there are many Petalangan people still feel that they own ulayat land, because the grave of their ancestors is in the company area. However, they cannot access their ancestral tombs, because it is closed by the company's portal. Even for the people of Petalangan, between nature and existence of life are intertwined and cannot be separated from each other. This is where the conflicts between indigenous peoples and companies emerge.

Serious implications of the concession towards the existence of Petalangan society is a change in behavior patterns. From which previously familiar with nature, slowly-become unfamiliar with nature. Even more alarming, if this forbidden forest area is returned to the indigenous peoples -after The Rights of Land Use is over-, there is no guarantee for the people to return to perform the function of its culture. Because, the process of concessions that take years have eliminated the generations of Petalangan who understand the true pattern of ancestral culture of the Petalangan tribe.

Some Petalangan communities who are given palm oil are often only used for short-term consumptive purposes by way of sale. The background of this case, as well as yet unfamiliar people manage oil fields are also factors: first, the tradition of hunting and switching fields, which is far different from the farming, especially palm oil processing. Second, it is the lack of knowledge of the economic value of oil palm. They were bewildered by the dramatic jumps of the culture.
During this time, it is found the irony of the transitional concessions. Particularly related to a society that is indirectly forced to get to know about money. The process of knowing money is at least can be observed from: first, the shift value of sialang honey, from previously appeared as collective goods (public good), into a commodity that is traded. Its advantage is also not for the interests of communal, but the interests of a group of people only. Second, the compensation or sago heart in the form of money precisely worries Petalangan social capital. The reason is, because the compensation was given to batin ${ }^{3}$. Batin is a term for chiefs to each Petalangan community, also the ruler of the ulayat land. By doing so, logically if then this understanding about batin will be related to the social function as a guaranteed welfare under his leadership / territory. Batin that is not accustomed to managing finances, make the compensation money does not function socially and empowerment. The money runs out as short-term and medium-term consumer goods. When the money runs out, then automatically the function of customary institutions as welfare providers decreases. The decline in welfare functions in the custom's system has implications for the legitimacy or batin dignity. If batin dignity fall, of course it is potential to trigger social conflict.

\footnotetext{
${ }^{3}$ Batin di Pelalawan Sultanate is actually 30, but because one of batin is considered as breaking the customary law, he is expelled, so that until now the number of batin is only 29. Batin is chosen based on the family tree of Pelalawan Sultan (alur patuk). Sequentially, family tree of batin hereditary can be started from: Sultan, Datuk, Penghulu, Batin. Datuk in doing his function is more on assessor board of Sultan candidate. They are now four persons. Datuk can be dismissed if he is proven to violate the customary law, pass away, and resign. Datuk is seen as worth and appropriate by custom assemblies, the same as MPR. Sultan himself is chosen by considering four criteria: his religion, track record of his behavior, Sultan is prioritized from young brother, and has to be chosen by four Datuk.
} 
SFM Form in the Management of Pelalawan Forest

Modernization has become an unavoidable necessity. This is also realized by observers of Melayu culture and Pelalawan Melayu Traditional Organization (LKAM) Institution. To respond to Pelalawan cultural disorientation, Pelalawan cultural actors attempt to address these conditions by preparing customary tools to keep up with the times. Including also by communicating to one of the largest companies in Palalawan i.e. RAPP, so that indigenous people can be trained with an adaptive competence standards recruitment. This is important to be done so that the existence of the company can also be felt for the surrounding community, especially indigenous peoples. Therefore, the local government itself along with Palalawan humanists has established Palalawan College of Technology, with a concentration in industrial engineering and agro-technologies, which are adapted to the RAPP curriculum. The hope of this educational institution can answer the needs of the labor market for the Pelalawan community.

Not only to make adjustments or repositioning, local customary institutions also intensify regeneration at the level of Pelalawan's youth assemblies, united melayu group, and Pelalawan Student Association to preserve the custom of Pelalawan which began eroded by industrialization. Political arrangement, custom structure began to be revived. Begin its activation of the role of Sultan, Datuk, Penghulu, Batin, which is marked by the re-establishment of the palace of Pelalawan Sultanate in 2010 and was named the palace "wings". The construction of this wing palace involves RAPP and Local Government (Pemda). In accordance with the permendagri rules on customary and palace facilitation, the operation of this customary system is only entitled to customary territory, not formal government. This is intended to avoid any managerial overlap and governance within the government structure. Only indeed the challenge to revive this custom is ulayat land as what Tengku says 'it is existed but there is none', because it is controlled by the company. In addition, the tribe as a psychotherapy prerequisite exists, and the last one is: mapping the historical genealogy or genealogy of the mind itself.

At every seven days before the month of Ramadan, in the wing palace there is an activity called belimau sultan. All citizens seemed to be taken to the memoir of a hundred years ago; everyone will be dressed like royal member of the kingdom, which depicts the greatness of each. The most eagerly awaited part, when the sultan gives the command of the mandate: first, religious advice. Second, like a bell to signify that we have entered the month of Ramadan.

To optimize the cultural dignity reconstruction efforts of Pelalawan, custom and local government institutions proposed customary village regulations (Perda), aiming at: (1) to make the village to be managed customarily, (2) to give space to revive customary tools in village structures for the matters that are customary, (3) as well as setting the management of the ulayat land rights, which most of them formally have been moved its ownership. Hopefully, custom hierarchy: Sultan, Datuk, Penghulu, Batin are recognized by giving them honorarium (honor or salary per month) as a form of recognition from the state for the existence of Palalawan custom. Including the official car facility for the Sultan from the government, which is now been applied. The proposed regulation also includes customary courts to resolve problems in communities where the case level is possible to be amicably resolved.

\section{Conclusion}

Development is an unavoidable necessity. The more development of a country, the more interests to be accommodated and the 
greater the tradeoffs that occur included in the utilization of forest resources in development. The huge consequence of the development of the forest is to maintain forest sustainability in the future so that it can be enjoyed not only by the present generation but also future generations. Therefore, it takes good forest governance so that SFM can be realized. In fact, the various practices that are directed towards good forest governance in Indonesia is still not able to run optimally because it has not been able to accommodate the interests of all the actors inside of it in a balanced way, especially the interests of indigenous peoples who seem to be the most disadvantaged. To be able to run well then good forest governance must be accompanied by cultural governance and ensure the interests and sustainability of indigenous peoples and its culture towards the forest.

Learning from what happens on Palalawan tribe, good forest governance can be seen on forest management in Palalawan indigenous peoples in Palalawan, City of Pangkalan Kerinci, Riau, involving RAPP as owners of land concessions, the government and indigenous peoples of Palalawan themselves. Dialogue between the three shows efforts to accommodate the interests of all three as an effort to achieve good forest governance. Palalawan indigenous people represented by its custom leaders to fight for the rights of their culture, while RAPP more towards the creation of conflict-free business, and government to act as a mediator. In the process of this dialogue, the process of cultural governance that provides space for indigenous peoples of Palalawan to maintain their culture happens. The forms of initiation of forest governance can be seen in the public communication of the RAPP to conduct competency training that fits the needs of companies for indigenous peoples and the establishment of Palalawan Technology College is collaboration between the regional government and indigenous peoples. It is expected to meet the required competencies that are needed by RAPP so that indigenous people can better benefit the company in terms of economy.

Attempts to revive the Palalawan culture is the real output of the process of cultural governance that happens. Customary device setup with the era, the regeneration of custom in the Palalawan youngsters, reviving the traditional structures, establishment of the wing palace involving RAPP and Local Government become the real evidence that cultural governance is able to accommodate the unprecedented threat to the culture of indigenous peoples of Palalawan thus giving a positive boost to the forest governance that is done, although to revive ulayat land is still difficult to do.

The synergy between good forest governance and cultural governance is absolutely necessary to be given regarding the characteristics of forests in Indonesia are most directly related to indigenous peoples. It is expected that the emergence of security against the preservation of indigenous cultures that created partnerships that is accommodative and further able to realize SFM.

\section{Aknowledgement}

This research was supported by FORBIL INSTITUTE that greatly funded and guided along of the project as well as all colleagues thosehmm assisted on data collection. We are very thanks to Dr. Bevaola Kusumasari who able to facilitate on publication process.

\section{References}

Agere, S. (2000). Promoting good governance Principles, Practices, and perspectives. London: Commonwealth Secretariat.

Baxter, P. \& Jack, S. (2008). Qualitative case study methodology: study design and implementation for novice researcher. The Qualitative Report 13(4). 
Cagalanan, D. (2015). Governance challenges in community-based forest management in the philippines. Society and Natural Resources, 28, 609-624.

Castrén, T. \& Madhavi P. (2011). Forest governance 2.0: A primer on ICTs and governance. Washington DC: Program on Forests (PROFOR).

Collier, P. (2007). The bottom billion: Why the poorest countries are failing and what can be done about it. Oxford: Oxford University Press.

Creswell, J. W. (2002). Research design: Qualitative, quantitative, and mixed methods approaches. (second edition). London: Sage Publications.

Cronkleton, P., Bray, D. B., \& Medina, G. (2011). Community Forest Management and the Emergence of Multi-Scale Governance Institutions: Lessons for REDD Development from Mexico, Brazil and Bolivia. Forests 2(4), $451-473$. doi:10.3390/f2020451

FAO. (2003). Sustainable forest management and the ecosystem approach: two concepts, one goal. Wilkie M.L., Holmgren P., Castaneda F. FAO Working Paper FM 25.

Grober, U. (2007). Deep Roots - A Conceptual History of "Sustainable Development" (Nachhaltigkeit). Wissenschaftszentrum Berlin für Sozialforschung.

Hardiani, K. (2017). Tata Kelola Hutan Rakyat di Kabupaten Pelalawan (Studi Kasus: Rehabilitasi Hutan dan Lahan). Jurnal Online Mahasiswa FISIP Universitas Riau 4(1), 1-11.

Lamicchane, D. \& Parajuli, R. (2014). How Good is the Governance Status in Community Forestry? A Case Study from Midhills in Nepal. Journal of Ecosystems, 2014, 1-7. doi:10.1155/2014/541374

Lemos, M. C. \& Arun A. (2006). Environmental Governance. Annual Review of Environmental Resources, 31, 297-325.

Lertzman, D. A. \& Vredenburg, H. (2005). Indigenous Peoples, Resource Extraction and Sustainable Development: An Ethical Approach. Journal Business Ethic, 56(3), 239-254. doi:10.1007/s10551-004-3528-8

Massiri, S. D., Nugroho, B., Kartodihardjo, H., \& Seokmadi, R. (2016). Preferensi dan Motivasi Masyarakat Lokal dalam Pemanfaatan Sumberdaya Hutan di Taman Nasional Lore Lindu, Provinsi Sulawesi Tengah. Jurnal Masyarakat dan Lingkungan, 23(2), 215-223. doi:10.22146/ jml.18793

Mayers, J., Bass, S., \& MacQueen, D. (2002). The Pyramid: A Diagnostic and Planning Tool for Good Forest Governance. Washington, D.C.: World Bank Alliance for Forest Conservation and Sustainable Use.

Moon, M. J. (2001). Cultural Governance a Comparative Study of Three Cultural Districts. Administration \& Society, 33(4), 432-454. doi: 10.1177/0095399701334003

Mutekwa, V., \& Gambiza, J. (2016). Assessment of Governance Principles Application in Forest Protected Areas: The Case of Six State Forests in Western Zimbabwe" International Forestry Review, 18(4), 466 484. doi:10.1505/146554816820127613

Jones, N., Sophoulis, C. M., Iosifides, T., Botetzagias, I., \& Evangelinos, K. (2009). The Influence of Social Capital on Environmental Policy Instruments. Environmental Politics, 18(4), 595-611. doi:10.1080/09644010903007443

Johansson, J. (2013). Towards democratic and effective forest governance? The discursive legitimation of forest certification in northern Sweden. Environment: The International Journal of Justice and Sustainability, 19(7), 803-819. doi:10.1080/13549839.2013.792050

Patel, L., Kaseke, E. \& Midgley, J. (2012). Indigenous Welfare and CommunityBased Social Development: Lessons from African Innovations. Journal of Community Practice, 20(1-2), 12-31. doi: 10.1080/10705422.2012.644217 
Pokharel, R. K., \& Tiwari, K. R. (2013). Good Governance Assessment in Nepal's Community Forestry. Journal of Sustainable Forestry, 32(6), 549-564. doi:10.1080/10549811.779902

La[alombara, J. \& Putnam, R. D. (1993). Making Democracy Work: Civic Traditions in Modern Italy. Political Science Quarterly, 108(3), 549. doi:102307/2151707

Stiglitz, J. E. (2000). Economics of the Public Sector. New York: WW Norton and Company.

Ramadhani, A. (2010). Promoting Good Forest Governance for Sustainable Livelihood Improvement: A Tanzanian Example. XIII World Forestry Congress; Unasylva, (FAO), 61, 54-59.

Sachs, J. D. (2015). The age of sustainable development. New York: Columbia University Press.
Schmitt, T.M. (2009). Global cultural governance. Decision-making concerning world heritage between politics and science. Erdkunde, 63(2), 103-121. doi:10.3112/ erksunde.2009.02.01

World Commission on Environment and Development. (1987). Report of the world commission on environment and development: Our Common Future, http://www.un-documents.net/ourcommon-future.pdf.

Forests sourcebook: practical guidance for sustaining forests in development cooperation. (2008). Washington, D.C.: World Bank.

Yuda, T. K. (2016). Memaknai ulang corporate social responsibility: Upaya mewujudkan fair responsibility. Jurnal Ilmu Sosial dan Ilmu Politik, 19(3), 200-2017. doi:10.22416/ jsp.15680 